[Vol. 128:650

\title{
STOCK REDEMPTIONS AND THE ESTATE-ATTRIBUTION RULES
}

\section{INTRODUCTION}

When a corporation redeems its stock, the amount received by the shareholder is treated for tax purposes as either a dividend or sale. ${ }^{1}$ If a dividend, the amount is included in the shareholder's income and taxed in full; ${ }^{2}$ if a sale, the amount is treated in part as a tax-free return of the shareholder's basis in the stock, ${ }^{3}$ and the remainder may give rise to a capital-gain deduction, reducing the shareholder's tax on that transaction by $60 \%{ }^{4}$ Sections 302 and 318 of the Internal Revenue Code contain complex rules for determining whether the amount is a dividend or sale: section 302 tells a shareholder by how much he must reduce his corporate ownership in order to treat the redemption as a sale; section 318 helps define that ownership by attributing to the shareholder stock actually owned by others.

This Comment considers attribution of stock to estates under section 318 (the "estate-attribution rules"), with particular atten-

1 See I.R.C. $\$ \S 301(\mathrm{c}), 302$.

${ }^{2}$ See id. $\S 301$ (c)(1).

3 See id. $\$ 301(\mathrm{c})(2)$.

"Basis" is a technical but important tax concept which is usually equivalent to the cost of property. See $i d$. $\$ 1012$. By paying tax on only the proceeds of a sale of property in excess of basis, id. $\$ \$ 301(\mathrm{c})(3), 1001(\mathrm{a})$, the taxpayer recoups his original investment without tax consequences and is taxed only on the gain or loss. The uninitiated reader who wishes to explore the mysteries of this concept may do so in the basic text, M. Chirelstein, Federal Income Taxatron (1977).

One relevant exception to the cost-as-basis rule is inherited property. An estate's basis in inherited property is "stepped up" to its fair market value at the time of the decedent's death. I.R.C. $\$ 1014(\mathrm{a})$. As this Comment goes to press, the status of stepped-up basis is uncertain. The Tax Reform Act of 1976 substituted carryover basis for stepped-up basis effective December 31, 1976. Pub. L. No. $94-455, \S 2005(\mathrm{a})(2), 90$ Stat. 1520 (1976) (codified as amended in I.R.C. $\$ 1023)$. Congress then postponed the substitution for three years. Revenue Act of 1978, Pub. L. No. 95-600, $\$ 515(3),(4), 92$ Stat. 2763 (codified in I.R.C. $\$ 1023(\mathrm{a})$ ). Currently, both houses have approved repeal of carryover basis in the form of riders attached to separate "windfall profit" oil-tax bills. 48 U.S.L.W. 2432 (1980).

4 See I.R.C. $\$ \S 301(c)(3), 1202$.

5 See generally Willens, Recent Decisions Open the Way for Trusts and Estates to Waive Stock Attribution, 5I J. TAx. 208 (1979). For more general discussion of $\$ \$ 302$ and 318 , see B. BitTKER \& J. Eustice, Federal Income Taxation of Corporations and Shareholders fff 9.20- 26 (4th ed. 1979); 1 J. Mertens, The LAW of FEDERAL InCOME TAXation \$9.105 (Malone ed. 1974 \& Supp. Doheny ed. 1979); Cavitch, Problems Arising From the Attribution Rules, 35 N.Y.U. Irst. FED. TAX. 801 (1977); Loeb, What Constitutes Ownership of Stock, 21 N.Y.U. InSt. FED. TAX. 417 (1963); Ringel, Surrey \& Warren, Attribution of Stock Owner- 
tion to the recent case of Rickey $v$. United States. ${ }^{6}$ In Rickey, the Fifth Circuit conceded that under a literal reading of the Code, a beneficiary's stock must be attributed to an estate under sections 302(c) and 318 (a) (3). ${ }^{7}$ The court nevertheless held that the Rickey estate could waive the attribution rules ${ }^{8}$ and thereby treat a redemption as a sale. The court justified its decision by saying, "the rationale for applying ... [the] rule is absent, and ... application of the rule leads to inappropriately harsh results." ${ }^{\circ}$

The underlying issue in Rickey is significant because the amount of money at stake may be large and the potential for abuse great. For instance, because the redemption in Rickey qualified as a sale and the estate's basis in the stock was stepped up to the stock's fair market value, ${ }^{10}$ no tax was due. The Internal Revenue Service, on the other hand, had argued that the redemption was a dividend and thus taxable as ordinary income. ${ }^{11}$ It therefore assessed each beneficiary a tax deficiency in excess of $\$ 24,000 .^{12}$ Thus, more than $\$ 72,000$ in taxes hinged on whether the redemption was taxable as a dividend or sale.

The Fifth Circuit's holding is problematic. It can be read as allowing stockholders routinely to include in their wills a provision directing their estates to offer their shares to the corporation; the estates and the beneficiaries would then ignore the attribution rules and treat the redemptions as sales. The results, as in Rickey, would be substantial reductions in taxes. This result would contravene congressional intent ${ }^{18}$ and abuse the rationale of the statute.

ship in the Internal Revenue Code, 72 HaRv. L. Rev. 209 (1958). See also Cathcart, Section 302 Redemptions: Family Fights and Attribution, 61 A.B.A.J. 1272 (1975).

6592 F.2d 1251 (5th Cir. 1979).

7 Id. 1257.

8 Id. 1258.

$9 \mathrm{Id}$.

10 See I.R.C. § 1014; note 3 supra.

11592 F.2d at 1253; see I.R.C. $\$ 301$ (c)(1).

12 The exact amount of the deficiency cannot be calculated from the information in the opinions; however, the estimate illustrates that the amounts involved are substantial. The calculation was made as follows. (All amounts were rounded off to the nearest dollar.) The amount of ordinary income to the estate was the proceeds of the redemption, $\$ 383,194$, less the amount used to pay death taxes, $\$ 228,991$, see I.R.C. $\$ 303-$ a total of $\$ 154,203$. Rickey v. United States, 427 F. Supp. 484, 486-87 (E.D. La. 1976); see Rickey, 592 F.2d at 1253-54. One-third of this total, or $\$ 51,401$, was taxable to each of the three beneficiaries. Id.; see I.R.C. \$662. Assuming that each beneficiary was an "individual," see I.R.C. §I(a) (1965), and that $\$ 51,401$ was his total taxable income, the tax could be calculated from the tax tables in effect for the appropriate year, 1968. The tax was $\$ 23,940$ plus $66 \%$ of the amount in excess of $\$ 50,000$. Id. Therefore, each beneficiary's tax was $\$ 24,865$.

18 See text accompanying notes 76-88 infra. 
To lay the foundation for a better understanding of estate attribution, this Comment will first describe the statutory scheme for taxation of stock redemptions. It will then consider the theory and policy of the attribution rules, with an analysis of the legislative history and case law concerning the attribution rules and stock redemptions. After describing the facts of Rickey and criticizing the Fifth Circuit's decision, the Comment will apply the theory and policy of the attribution rules to Rickey and propose a new analysis to be used when an estate's stock is redeemed by the corporation.

\section{The Statutory Scheme ${ }^{14}$}

The critical question when a corporation redeems its stock from a shareholder is whether (for tax purposes) the redemption is a sale of stock or a dividend. ${ }^{15}$ Under section $302(b)$, a shareholder must reduce his ownership interest for the redemption to be treated as a sale and thereby gain favorable tax treatment. ${ }^{16}$ It is possible for a shareholder to "sell" several of his shares back to the corporation without having his claim to the assets of the corporation or voting rights reduced; ${ }^{17}$ for example, if the owner of all of the shares of a corporation sells some of them back to the corporation, he is, in reality, merely withdrawing accumulated earnings. He has not suffered the reduction in ownership interest that normally accompanies a sale: he still owns all of the outstanding stock and has not reduced his proportionate claim to the assets of the corporation or his voting rights. $\mathrm{He}$ is thus properly taxed as if he had received a dividend. Taxation of a redemption as a sale or dividend therefore depends on the shareholder's ownership interest in the stock both before and after the redemption. "The hallmarks of a dividend ... are pro rata distribution of earnings and profits and no change in basic shareholder relationships." 18

The shareholder's ownership of stock is partially determined by the constructive-ownership rules of section 318 , which attribute

14 The provisions of the Internal Revenue Code that are directly relevant to Rickey v. United States, 592 F.2d 1251 (5th Cir. 1979), are $\$ \oint 301,302$, and 318.

15 The question is important because dividends, which are distributions of earnings and profits, are taxed at ordinary rates while sales of capital assets such as stock are taxed at favorable capital-gain rates. See notes $1-4$ supra \& accompanying text.

16 See text accompanying notes 26-53 infra.

17 The Second Circuit has defined three shareholder interests: the rights "( 1 ) to vote, and thereby exercise control, (2) to participate in current eamings and accumulated surplus, and (3) to share in net assets on liquidation." Himmel v. Commissioner, 338 F.2d 815, 817 (2d Cir. 1964).

18 Id. See also Cathcart, supra note 5; Postlewaite \& Finneran, Section 302 (b)(1): The Expanding Minnow, 64 VA. L. REv. 561 (1978). 
one taxpayer's stock ownership to another. These attribution rules prevent a shareholder from treating a. redemption as a sale when certain relatives or entities maintain a sufficient interest such that his own ownership interest effectively continues. ${ }^{19}$

\section{A. The Constructive-Ownership Rules ${ }^{20}$}

To prevent tax avoidance, ownership of stock by one person or entity may be attributed to a second person or entity. The family-attribution rules provide that an individual is deemed to own stock owned by his spouse, children, grandchildren, and parents. $^{21}$ The estate-beneficiary attribution rules provide that an estate is deemed to own stock that is actually or constructively owned by its beneficiaries, ${ }^{22}$ and that a beneficiary is deemed to own stock owned by an estate in an amount equal to his proportionate interest in the entire estate. ${ }^{23}$ Double attribution is not allowed in certain circumstances; ${ }^{24}$ in particular, stock held constructively by an estate through one beneficiary may not be reattributed to a second beneficiary. ${ }^{25}$

These rules may be illustrated as follows: Suppose father and son each own $50 \%$ of a corporation. If the father dies and his wife is sole beneficiary, she will be deemed to own $100 \%$ of the stock of the corporation: she will constructively own the son's $50 \%$ through the family-attribution rules and constructively own the shares held by the estate through the estate-to-beneficiary rule. The estate will likewise be deemed to own $100 \%$ of the corporation:

19 The rationales for the attribution rules-guidance for taxpayers and prevention of tax avoidance-will be discussed in part II, text accompanying notes 54-88 infra.

20 I.R.C. $\$ 318$ (a). Other constructive-ownership rules, not relevant to this Comment, are embodied in $\$ \S 267,544$, and 671 . See generally Ringel, Surrey, \& Warren, supra note 5.

21 "An individual shall be considered as owning the stock owned, directly or indirectly, by or for-(i) his spouse, ... and (ii) his children, grandchildren, and parents." I.R.C. $\$ 318(\mathrm{a})(\mathrm{I})(\mathrm{A})$. Note that stock is not attributed among siblings.

22 "Stock owned, directly or indirectly, by or for . . a beneficiary of an estate shall be considered as owned by the ... estate." Id. $\$ 318(a)(3)(A)$.

23 "Stock owned, directly or indirectly, by or for $a[n] .$. estate shall be considered as owned proportionately by its ... beneficiaries." I $\dot{d}$. $\S 318(\mathrm{a})(2)(\mathrm{A})$. Other rules attribute stock of and to trusts, id. $\$ 318(\mathrm{a})(2)(\mathrm{B}),(\mathrm{a})(3)(\mathrm{B})$, and corporations, id. $\$ 318(a)(2)(\mathrm{C}),(\mathrm{a})(3)(\mathrm{C})$, and attribute stock options, $i d$. $\$ 318(\mathrm{a})(4),(\mathrm{a})(\mathrm{S})(\mathrm{D})$.

24 Id. $\$ 318(a)(5)(A)-(C)$.

20 "Stock constructively owned by . . . [an] estate . . . by reason of the application of paragraph (3) [(beneficiary-to-estate attribution, see note 22 supra)] shall not be considered as owned by it for purposes of applying paragraph (2) [(estate-to-beneficiary attribution, see note 23 supra)] in order to make another the constructive owner of such stock." I.R.C. $\$ 318(a)(5)(C)$. 
the $50 \%$ that it actually owns and the $50 \%$ that is attributed from son to wife through family attribution, and then reattributed from wife to the estate through beneficiary-to-estate attribution.

\section{B. The Stock-Redemption Rules}

The rules relating to stock redemptions ${ }^{26}$ are complex. If a corporation redeems its stock and the shareholder meets certain specific ownership criteria, ${ }^{27}$ the redemption is treated as a sale of the stock and the transaction taxed at capital-gain rates. ${ }^{28}$ If these criteria are not met, the transaction is treated as a dividend and taxed at ordinary rates. ${ }^{29}$ In determining whether these ownership criteria are met, the constructive-ownership rules apply. ${ }^{30}$

\section{The Complete-Termination Test}

Section 302(b) (3) is a safe-harbor provision-a mechanical rule guaranteeing favorable treatment for the complying taxpayer. It is the simplest of the corporate redemption provisions to understand and apply. It is also the most difficult requirement to meet: ${ }^{31}$ a shareholder must dispose of his entire interest in the corporation. $^{32}$ If he does, he may treat the redemption as a sale of the stock and gain favorable tax treatment. Because the attribution

20 I.R.C. $\$ 302$.

27 These criteria are specified in id. $\$ 302(b)(1)-(3)$. Section $302(b)(4)$, relating to redemption of stock of bankrupt railroads, is special-interest legislation not relevant to this Comment.

28 "If a corporation redeems its stock . . . and if $[\$ 302(b)(1)-(3)] \ldots$ applies, such redemption shall be treated as a distribution in part or foll payment in exchange for the stock." I.R.C. $\$ 302(a)$. See generally text accompanying notes 1-4 supra.

29 See I.R.C. $\$ \$ 301(c)(1), 302,316(a)$.

30 'Except as provided in $[\$ 302(c)(2)$ (waiver of family attribution for purposes of the complete-termination test) $]$... . section 318(a) shall apply in determining the ownership of stock for purposes of this section." Id. $\$ 302$ (c)(1).

31 Each of the three relevant provisions of I.R.C. $\$ 302(b)$ calls for the taxpayer to reduce his interest in the corporation to some extent. Section 302 (b)(1) has been interpreted as calling for a "meaningful reduction" of interest. United States v. Davis, 397 U.S. 301, 313 (1970). Section $302(\mathrm{~b})(2)$ requires a distribution to be "substantially disproportionate with respect to the shareholder." Section 302 (b) (3) requires the shareholder to dispose of all of his shares in the corporation. At first glance it appears that $\S 302(\mathrm{~b})(3)$ is unnecessary because a complete termination of interest will always be substantially disproportionate. Section 302 (c) (2), however, provides for nonapplication of the family-attribution rules if a shareholder terminates his actual ownership interest. See note 36 infra \& accompanying text. This provision is not available when the taxpayer relies on $\S 302(\mathrm{~b})$ (2). The concept of reduction in ownership interests will be discussed further in part II infra.

$\mathbf{8 2}$ "[Section 302(a) will apply] if the redemption is in complete redemption of all of the stock of the corporation owned by the shareholder." I.R.C. $\$ 302(b)(3)$. 
rules apply, however, the redemption will not be a complete termination of interest and will be taxed as a dividend at the ordinary tax rates if certain relatives, ${ }^{33}$ an estate of which the shareholder is a beneficiary, ${ }^{34}$ or any other section 318 (a) entity ${ }^{35}$ holds stock in the corporation. Section 302(c)(2) allows a shareholder who has had all of his shares redeemed by the corporation to "waive" the family-attribution rules if he agrees to forego any interest in the corporation, except as a creditor, for ten years. ${ }^{38}$ Upon filing the waiver agxeement, the shareholder can have the redemption treated as a sale of his interest (provided no other attribution rule

33 Id. $318(a)(1)$; see note 21 supra.

34 I.R.C. $\$ 318(\mathrm{a})(2)(\mathrm{A})$; see note 23 supra.

35 See note 22 supra \& accompanying text.

88 The section reads, in relevant part:

(A) In the case of a distribution described in subsection (b)(3), section $318(a)(1)$ shall not apply if-

(i) immediately after the distribution the distributee has no interest in the corporation (including an interest as officer, director, or employee), other than an interest as a creditor,

(ii) the distributee does not acquire any such interest (other than stock acquired by bequest or inheritance) within 10 years from the date of such distribution, and

(iii) the distributee, at such time and in such manner as the Secretary by-regulations prescribes, files an agreement to notify the Secretary of any acquisition described in clause (ii) and to retain such records as may be necessary for the application of this paragraph.

(B) Subparagraph (A) of this paragraph shall not apply if-

(i) any portion of the stock redeemed was acquired, directly or indirectly, within the 10-year period ending on the date of the distribution by the distributee from a person the ownership of whose stock would (at the time of distribution) be attributable to the distributee under section $318(\mathrm{a})$, or

(ii) any person owns (at the time of the distribution) stock the ownership of which is attributable to the distributee under section 318(a) and such person acquired any stock in the corporation, directly or indirectly, from the distributee within the 10-year period ending on the date of the distribution, unless such stock so acquired from the distributee is redeemed in the same transaction.

The preceding sentence shall not apply if the acquisition (or, in the case of clause (ii), the disposition) by the distributee did not have as one of its principal purposes the avoidance of Federal income tax.

I.R.C. $\S 302(\mathrm{c})(2)$.

Note that $\S 302$ (c) provides for waiver only by the "distributee" (the person who sells the shares to the corporation) and allows waiver only of family attribution. Id. $\$ 302(\mathrm{c})(\mathrm{I})$.

In Crawford v. Commissioner, 59 T.C. 830 (1973), the court considered whether a beneficiary could waive family attribution when the estate was the owner of the shares being redeemed. The court did not rule on the effectiveness of this waiver; however, it did allow the estate to waive the family-attribution rules. The Commissioner has announced nonacquiescence in this decision. 1974-2 C.B. 5.

For a complete discussion of the mechanics of waiver, see Cavitch, supra note 5 , at 822-31. 
is applicable). This is the only provision for waiver of attribution rules. ${ }^{37}$

\section{The Substantially-Disproportionate Test ${ }^{38}$}

Like the complete-termination test, the substantially-disproportionate test of section 302(b) (2) delimits a safe harbor. It has two major components. Under the first, after the redemption the taxpayer must own less than $50 \%$ of the total "voting power of all classes of stock entitled to vote." 39 Under the second, the shareholder must reduce his proportionate ownership of the voting stock of the corporation by more than $20 \%{ }^{40}$ As before, ${ }^{41}$ the attribution rules are applied to determine ownership. If the taxpayer meets these mathematical tests, he is entitled to treat the redemption as a sale and be taxed at capital-gain rates. ${ }^{42}$

This provision may be illustrated as follows: Suppose a shareholder owns sixty of the one hundred outstanding shares of the corporation. If he redeems thirteen shares, he will not qualify for capital-gain treatment because after the redemption he will own more than $50 \%$ of the stock outstanding. ${ }^{43}$ If he redeems twenty-

37 I.R.C. $\$ 302$ (c) (I); see note 30 supra.

38 I.R.C. $\S 302(\mathrm{~b})(2)$. A detailed analysis of this section is beyond the scope of this Comment.

89 Id. $\$ 302$ (b)(2)(B). This is the "50\% test."

40 The section reads in part:

For purposes of this paragraph, the distribution is substantially disproportionate if-

(i) the ratio which the voting stock of the corporation owned by the shareholder immediately after the redemption bears to all of the voting stock of the corporation at such time,

is less than 80 percent of-

(ii) the ratio which the voting stock of the corporation owned by the shareholder immediately before the redemption bears to all of the voting stock of the corporation at such time.

Id. $\$ 302(\mathrm{~b})(2)(\mathrm{C})$. This is the "20\% test" This is sometimes referred to as the "80\% test." E.g., J. Mertens, supra note $5, \$ 9.105$ at ch. 9, 345-47.

The redeeming stockholder's proportionate ownership of all common stock (whether voting or nonvoting) must also be reduced by over $20 \%$ :

For purposes of this paragraph, no distribution shall be treated as substantially disproportionate unless the shareholder's ownership of the common stock of the corporation (whether voting or nonvoting) after and before redemption also meets the 80 percent requirement of the preceding sentence. For purposes of the preceding sentence, if there is more than one class of common stock, the determinations shall be made by reference to fair market value.

Id.

41 See note 30 supra \& accompanying text.

42 I.R.C. $\$ 302(a)$.

48 After redeeming 13 shares, the shareholder owns 47 of the 87 outstanding shares, or 54\%. This redemption also fails the $20 \%$ test; the stockholder has reduced 
four shares, the redemption is substantially disproportionate because he will then own less than $50 \%$ of the stock outstanding, ${ }^{44}$ and his proportionate interest in the corporation will be reduced by more than $20 \%$, from $60 \%$ to $47 \%$. Thus, the redemption of twenty-four shares is treated as a sale.

\section{The Not-Equivalent-to-a-Dividend Test}

Section 302(b)(1) provides for capital-gain treatment if the redemption is "not essentially equivalent to a dividend." 45 This is a vague test in which the facts and circumstances of each case are paramount; ${ }^{46}$ it has been the subject of much litigation. ${ }^{47}$ Reliance is placed on this provision only if the taxpayer fails to meet the safe-harbor provisions of either the complete-termination or substantially-disproportionate test. ${ }^{48}$

The leading case interpreting section $302(\mathrm{~b})(1)$ is United States v. Davis. ${ }^{49}$ In Davis, the taxpayer owned $100 \%$ of the preferred stock and $25 \%$ of the common stock of a corporation, and his wife and two children each owned $25 \%$ of the common. The corporation redeemed all of the preferred from the taxpayer, who argued that the attribution rules do not apply to section $302(b)(1)$, so that he should have been "considered to own only 25 percent of the corporation's common stock, and the distribution would then qualify under $\S 302(b)(1)$ since it was not pro rata or proportionate to his stock interest, the fundamental test of dividend equivalency." so

The Supreme Court rejected this argument, holding that the attribution rules do apply to section $302(\mathrm{~b})(1) .^{51}$ The Court stated that the proper test to be used under this section is whether the redemption results in a "meaningful reduction of the shareholder's

his proportionate interest by only 10\%. (This and all percentages in this Comment are rounded to the nearest $1 \%$.)

44 After the redemption of 24 shares, the shareholder owns 36 of the 76 outstanding shares, or $47 \%$.

45 I.R.C. $\$ 302(b)(1)$.

46 See Treas. Reg. $\$ 1.302-2$ (b) (1955).

47 See, e.g., Haft Trust v. Commissioner, 510 F.2d 43 (1st Cir. 1975); Title Ins. \& Trust Co. v. United States, 484 F.2d 462 (9th Cir. 1973); Commissioner v. Berenbaum, 369 F.2d 337 (10th Cir. 1966).

48 See B. BrTrken \& J. Eustrce, supra note 5, $\int 9.20$, at 9-11 (4th ed. 1979) ("[T] $]$ his is a treacherous route to be employed only as a last resort.").

49397 U.S. 301 (1970).

s0 Id. 306.

51 Id. 307. 
proportionate interest in the corporation." 52 Thus, the reduction of ownership in Davis was not meaningful because the taxpayer owned $100 \%$ of the outstanding stock at all times: after the redemption he actually owned $25 \%$ and constructively owned $75 \%$. The Supreme Court's decision in Davis, however, has not ended section 302(b)(1) litigation; rather, it has shifted the focus of litigation to the question of what is a meaningful reduction of interest. ${ }^{53}$

To understand how this statutory scheme works, it is necessary to examine the underlying theory and congressional purpose in enacting the provision.

\section{Theory of Attribution and Its Relation to Redemptions}

\section{A. Basic Principles}

As has been shown, the first question to ask when a corporation redeems its stock is whether the redemption is a sale or a dividend. ${ }^{54}$ Section $302(b)$ contains three tests, based on the change in the taxpayer's ownership interest, for determining if a sale has occurred. ${ }^{55}$ The constructive-ownership rules of section $318^{56}$ are thus critical because of their effect on what is deemed to be part of that ownership interest. They were enacted by Congress to prevent tax avoidance ${ }^{57}$ and to allow tax planning by establishing precise standards so that a taxpayer can determine when he will be deemed to own stock actually owned by another. ${ }^{.8}$

The family-attribution rules ${ }^{59}$ are based upon the presumption that there is familial unity of control and interest. ${ }^{60}$ Thus, one spouse is presumed to have a significant degree of control over stock

52 Id. 313. The Court also held that the existence of a legitimate business purpose was irrelevant to the question of dividend equivalency under $\S 302(\mathrm{~b})(1)$. Id. 312 .

53 See, e.g., Rickey v. United States, 592 F.2d 1251 (5th Cir. 1979); Wright v. United States, 482 F.2d 600 (8th Cir. 1973); Rev. Rul. 75-502, 1975-2 C.B. 111. Cf. Haft Trust v. Commissioner, 510 F.2d 43 (1st Cir. 1975) (family hostility is factor to be considered in mitigation of constructive-ownership rules under $\$ 302$ (b)(1)). For a discussion of what interests are considered in making this determination, see Himmel v. Commissioner, 338 F.2d 815 (2d Cir. 1964). See generally Note, I.R.C. of $302(b)(1)$ : Dividend Equivalency After United States v. Davis, 7 Fra. ST. L. REv. 505 (1979).

54 See text accompanying notes 15-18 supra.

55 See text accompanying notes 26-53 supra.

56 See generally text accompanying notes $20-25$ supra.

57 See text accompanying note 82 infra. See generally, e.g., Ringel, Surrey \& Warren, supra note 5; 55 B.U. L. REv. 667 (1975).

58 See text accompanying notes 76-88 infra.

59 I.R.C. $\$ 318($ a $)(1)(A)$; see note 21 supra.

60 See B. BITTKER \& J. EUSTICE, supra note 5, I 9.23, at 9-26. 
owned by the other spouse, and a parent is presumed to have interests in common with his child. ${ }^{61}$ The attribution rules presume that when an individual's stock is redeemed by a corporation in which certain relatives also own stock, his ownership interest effectively continues. ${ }^{62}$

In some cases, however, this presumption may be invalid. Personal relationships are fragile, and "bad blood" may exist among relatives. Thus an individual may not be able to control stock owned by a relative. If family hostility is proven, courts have in fact found that the redemption is "not essentially equivalent to a dividend" under section $302(\mathrm{~b})(\mathrm{l})$ and, thus, have treated it as a sale of the stock. ${ }^{63}$ Courts have been flexible because section $302(\mathrm{~b})(1)$ is not rigid, ${ }^{64}$ as are the other provisions of section 302(b). Congress recognized the fragile nature of personal relationships and provided, in section 302(c)(2), for the waiver of the family-attribution rules when the shareholder terminates his actual ownership. ${ }^{65}$

The entity-attribution rules, ${ }^{66}$ on the other hand, are based on an identity of economic interests. ${ }^{67}$ A beneficiary will aid the estate because he ultimately will receive assets of the estate. Although he may dislike the executor, he will not normally sever his connection to the estate for this reason. Indeed, because an executor is in a fiduciary relationship with the beneficiaries, ${ }^{68}$ he must always work for their economic benefit, even if not always in accordance with their wishes.

This attribution rule, however, has also been circumscribed when it failed to reflect the economic interests accurately. The court in Estate of Arthur H. Squier, ${ }^{60}$ for example, held that demonstrated hostility between executor and beneficiaries was suf-

61 See Rickey v. United States, 592 F.2d 1251, 1256 (5th Cir. 1979).

62 See B. BrrTken \& J. Eustroe, supra note 5, at $\uparrow 9.23$, at 9-26.

63 See, e.g., Bradbury v. Commissioner, 298 F.2d 111, 116 n.7 (1st Cir. 1962); Estate of Arthur H. Squier, 35 T.C. 950 (1961); Herbert C. Parker, 20 T.C.M. 893 (1961). This principle has vitality even after United States v. Davis, 397 U.S. 301 (1970). See Haft Trust v. Commissioner, 510 F.2d 43 (1st Cir. 1975); Comment, Defining Dividend Equivalency Under Section 302(b)(I), 16 VInd. L. REv. 88, 105 (1970). But see Comment, Income Tax: Stock Redemption and the Test for Dividend Equivalency Under Section 302(b)(1) of the Internal Revenue Code of 1954, 23 U. FuA. L. REv. 188, 192 n.38 (1970). See generally Cathcart, note 5 supra.

It should be noted that, although the hostility in Squier was between executor and beneficiaries, that case is cited as involving family hostility. See note 108 infra.

${ }^{84}$ See Treas. Reg. $\$ 1.302-2$ (b) (1955).

65 I.R.C. $\$ 302(\mathrm{c})(2)$; see text accompanying notes 36-37 supra.

66 I.R.C. $\$ 318(\mathrm{a})(2),(3)$. See notes $22-23$ supra \& accompanying text.

67 See, e.g., B. BITrkeq \& J. Eustice, supra note 5, $\|$ 9.23, at 9-26.

88 Restatement (SECOND) OF Trusts $\$ 170$ (1959).

6935 T.C. 950 (1961). 
ficient reason to declare the redemption of the estate's stock "not essentially equivalent to a dividend" despite the attribution rules. Because of the hostility, the estate actually lost control of the corporation.

\section{B. Tax Avoidance and Estate Attribution}

Estate attribution works in two directions to prevent two methods of tax avoidance. The first is from beneficiary to estate: ${ }^{70}$ when an estate's stock is redeemed, consideration is given to the beneficiary's stock holdings. This attribution is necessary to prevent an estate from making transactions at capital-gain rates when the same transaction, if carried out by the beneficiary, would be taxed at ordinary rates. ${ }^{71}$ If estate and beneficiary were always taxed at the same rate, whether capital-gain (sale) or ordinary (dividend), ${ }^{72}$ there would be no tax-avoidance motivation; the attribution rules force this result. Because estates are usually shortlived, however, their stock may properly be viewed as effectively owned by the beneficiaries. ${ }^{73}$

The second direction of attribution is from estate to beneficiary. ${ }^{74}$ This type prevents a beneficiary from having his shares redeemed and then paying capital-gain taxes without considering shares held by the estate on his behalf. Again because estates are short-lived, the beneficiary, without attribution, could have his shares redeemed without effectively suffering a loss of his ownership, and yet be taxed as if he had sold his interest in the corporation. The attribution rules prevent this. ${ }^{75}$

70 I.R.C. $\$ 318(\mathrm{a})(3)(\mathrm{A})$; see note 22 supra.

71 See Ringel, Surrey, \& Warren, supra note 5, at 262.

72 Congress has sought to prevent tax avoidance by estates and beneficiaries in different tax brackets. Generally, the income of an estate will be taxed at the beneficiary's tax rate. See, e.g., I.R.C. $\$ \$ 661,662$.

73 When there are several beneficiaries, each may stand in a different tax posture and a redemption may be taxed differently for each. Thus, when the estate's stock is redeemed, some beneficiaries may have a tax-avoidance motive, while others may not. An extreme example occurs when one beneficiary owns all stock not owned by the estate, while the other beneficiaries own no stock. This is analogous to the situation in Rickey v. United States, 592 F.2d 1251 (5th Cir. 1979), and will be discussed in text accompanying notes 119-27 infra.

74 I.R.C. $\$ 318(\mathrm{a})(2)(\mathrm{A})$; see note 23 supra.

75 Under $\$ 318$ (a)(2)(A), a beneficiary is deemed to own the estate's stock in an amount proportional to his share of the entire estate, even if he does not inherit the estate's stock or the proceeds of its distribution. In this situation, if the beneficiary sells his own shares, he necessarily suffers a reduction in his interest in the corporation. Thus, here the rationale for estate-to-beneficiary attribution is lacking. See Ringel, Surrey \& Warren, supra note 5, at 217; text accompanying notes 119-66 infra. 
This rule may be illustrated as follows: Suppose a sole beneficiary owns a $33 \%$ interest in the corporation and the estate also owns $33 \%$. The beneficiary is thus deemed to own $66 \%$ of the corporation; if he has all of his stock redeemed, he will constructively hold $50 \%$ of the outstanding stock after the redemption. Estate-to-beneficiary attribution causes the beneficiary to be taxed as if he owned the estate's stock.

\section{Congressional Intent ${ }^{76}$}

Under the 1939 Code the sole test for determining the tax treatment of stock redemptions was the not-equivalent-to-a-dividend test. ${ }^{77}$ The House committee redrafting the Code in 1954 said about this vague test:

Under present law it is not clear when a stock redemption results in capital gain or ordinary income. ... In general, because of the considerable confusion which exists in this area, taxpayers have been faced with potential dividend-tax liability in many cases where such result is unwarranted, and in other cases have avoided such liability where the redemption was the equivalent of a dividend. ${ }^{78}$

The 1954 House proposal was designed to provide "definite conditions under which stock may be redeemed at capital-gain rates." 79 Instead of providing for an ad hoc inquiry in every case, the House bill set forth specific guidelines so that a taxpayer could ascertain in advance whether a redemption would be taxed as a dividend or sale. These provisions are the current sections 302 (b)(2) and 302(b) (3). The Senate found these rules "unnecessarily restrictive, particularly in the case of redemptions of preferred stock which might be called by the corporation without the shareholder

76 As has been demonstrated, two of the tests of $\$ 302$ are rigid and mechanical safe harbors, while the third grants some flexibility to the courts. See text accompanying notes 31-53 supra. Although the Code seems clear with respect to the rigid tests, the not-equivalent-to-a-dividend test is ambiguous, so a court would be justified in examining the legislative history to see how the more flexible rule relates to the others. Thus, although it is true that, "[w]hen a statute is unambiguous, the courts may not look elsewhere for the legislative intent," Easson v. Commissioner, 294 F.2d 653, 656 (9th Cir. 1961), the structure of section 302(b) suggests that a court's examination of the legislative history is appropriate, but only with respect to subsection (b)(1). (I)).

77 Int. Rev. Code of 1939 , ch. 1, $\$ 115$ (g), 53 Stat. 48 (now I.R.C. $\$ 302$ (b)

78 H.R. ReP. No. 1337, 83d Cong., 2d Sess. 35, reprinted in [1954] U.S. Cone CoNG. \& AD. NEws 4017,4060 [hereinafter cited as H. REP.].

78 Id. at 35, [1954] U.S. CODE CoNG. \& AD. News at 4061. 
having any control over when the redemption may take place." 80 The Senate then reinserted the "not essentially equivalent to a dividend" language in what became the current section $302(b)(1) .{ }^{81}$ In so doing, the Senate maintained some flexibility in the law.

Congress enacted the attribution rules to prevent tax avoidance and to permit tax planning. The House Report said that

[t]o prevent tax avoidance, but at the same time to provide definitive rules for the guidance of taxpayers, your committee has provided precise standards whereby under specific circumstances, a shareholder may be considered as owning stock held by members of his immediate family (or by partnerships, corporations, or trusts which he controls)..$^{82}$

Both houses of Congress intended the substantially-disproportionate test of section $302(\mathrm{~b})(2)$ to apply on a shareholder-by-shareholder basis. ${ }^{83}$ Thus, the same redemption could be a dividend for one shareholder and a sale for another.

The Senate explicitly stated that the complete-termination test must be read in conjunction with the constructive-ownership rules. ${ }^{84}$ The Senate committee discussed the waiver provisions of section 302(c)(2) and provided for their application only in the context of family attribution; no mention was made of waiver of entity attribution. ${ }^{85}$ The Senate also amended the House's attribution rules relating to estates; the House bill provided for attribution between an estate and a beneficiary only if the beneficiary had an interest of at least $50 \%$ in the estate, while the Senate version is the current law.

The legislative history indicates that the complete-termination and substantially-disproportionate tests, unlike the not-equivalentto-a-dividend test, are specific, mechanical rules. Furthermore, the Reports show that attribution should apply to the completetermination test, and specifically to the estate and beneficiary. ${ }^{.6}$

80 S. ReP. No. 1622, 83d Cong., 2d Sess. 44, reprinted in [1954] U.S. CoDE Cong. \& AD. NEws 4621, 4675 [hereinafter cited as S. REP.].

81 Id. at 44, [1954] U.S. Cope Cong. \& AD. News at 4675.

82 H. Rep., supra note 78, at 36, [1954] U.S. Code Cong. \& AD. News at 4061.

83 S. ReP., supra note 80 , at 234, [1954] U.S. CoDE Cong. \& AD. NEws at 4871; H. Rep., supra note 78, at A74, [1954] U.S. Code CoNG. \& AD. NEwS at 4211.

84 S. REP., supra note 80 , at 235, [1954] U.S. Cone CoNG. \& AD. NEws at 4872. 85 Id. at 235-36, [1954] U.S. CoDe CoNG. \& AD. NEWs at 4872-73.

86 These conclusions are central to a critique of the decision in Rickey $v$. United States, 592 F.2d 1251 (5th Cir. 1979). See text accompanying notes 101-16 infra. 
Section 302 is thus a complex provision designed to add certainty to the tax laws and provide definite guidance to taxpayers. The safe-harbor provisions of sections $302(\mathrm{~b})(2)$ and $302(\mathrm{~b})(3)$ provide taxpayers with mechanical tests; section $302(\mathrm{~b})(1)$ provides for relief when the mechanical tests are not met but the redemption should still not be taxed as a dividend. Only in the last test is there an inquiry into the facts and circumstances of each case, ${ }^{87}$ with the key question whether the redemption has resulted in a meaningful reduction of the shareholder's interest. Especially because Congress has provided different tests for different situations, courts should be reluctant to deviate from this deliberate statutory scheme. As the Third Circuit has said about the tax statute in general:

Efforts are made continuously, on the one side, to close the gaps through which taxpayers have escaped untaxed, and, on the other to provide relief for the taxpayer in a hardship position. Corrective legislation with respect to the taxing statute has been the continuous duty of the legislative branch. Certain areas of the Code have been phrased in broad terms which sometimes prove provocative of judicial legislation. However, detailed sections of the Code have left little room for the engraftment of judicial addenda to the end of making a "better" statute. A more literal interpretation of the statute consistent with the established meaning of the previously used legislative wording is the only method compatible with such detail. ${ }^{88}$

\section{The Problem of Rickey}

The recent case of Rickey $v$. United States ${ }^{89}$ highlights the problems that can occur when a court both strays from a strict application of section 302 and misperceives the theory of attribution and congressional intent.

\section{A. Estate's Position Under Section 302}

In Rickey, Horace B. Rickey, Sr. ("Rickey") was president and principal shareholder of Horace B. Rickey, Inc. When Rickey died, the corporation, under a mandatory provision of its bylaws, ${ }^{30}$ re-

${ }^{87}$ See Treas. Reg. $\$ 1.302-2(b)$ (1955). Business purposes are irrelevant to this determination. See notes 49-52 supra \& accompanying text.

88 St. Louis Co. v. United States, 237 F.2d 151, 157-58 (3d Cir. 1956).

89592 F.2d 1251 (5th Cir. 1979).

90 The provision literally called only for an option to repurchase the shares, but the shareholders viewed the provision as mandatory. The corporation maintained 
deemed his stock from his estate. Three of the estate's beneficiaries -Horace B. Rickey, Jr. ("Junior"), who was also a corporate officer, and two of Rickey's minor children-owned shares of the corporation. The distribution of actual ownership before and after redemption can be summarized as follows: ${ }^{91}$

\section{Distribution OF OWNERShIP}

\begin{tabular}{|c|c|c|c|c|}
\hline & \multicolumn{2}{|c|}{$\begin{array}{c}\text { Before } \\
\text { Redemption }\end{array}$} & \multicolumn{2}{|c|}{$\begin{array}{c}\text { After } \\
\text { Redemption }\end{array}$} \\
\hline & Shares & $\%$ & Shares & $\%$ \\
\hline Estate & 1292 & $57 \%$ & - & - \\
\hline Junior & 708 & $31 \%$ & 708 & $74 \%$ \\
\hline Minor Children & n 80 & $4 \%$ & 80 & $8 \%$ \\
\hline Others & 175 & $8 \%$ & 175 & $18 \%$ \\
\hline Total & 2255 & $100 \%$ & 963 & $100 \%$ \\
\hline
\end{tabular}

Under the literal terms of the Code, the estate was in a poor tax position. Because of section $302(c)(1),{ }^{92}$ the stock of the beneficiaries (Junior and the minor children) was attributed to the estate as follows: ${ }^{93}$

\section{ESTATE'S OWNERSHIP}

\begin{tabular}{|c|c|c|c|c|}
\hline & \multicolumn{2}{|c|}{$\begin{array}{c}\text { Before } \\
\text { Redemption }\end{array}$} & \multicolumn{2}{|c|}{$\begin{array}{c}\text { After } \\
\text { Redemption }\end{array}$} \\
\hline & Shares & $\%$ & Shares & $\%$ \\
\hline Actual & 1292 & $57 \%$ & 0 & $0 \%$ \\
\hline Constructive & 788 & $35 \%$ & 788 & $82 \%$ \\
\hline Total & 2080 & $92 \%$ & 788 & $82 \%$ \\
\hline
\end{tabular}

The redemption of stock did not seem to qualify for favorable tax treatment as a sale under any part of section 302. There was no complete termination of interest under section $302(\mathrm{~b})(3)^{9 *}$ be-

insurance on the lives of key shareholders for the purpose of having enough cash to exercise the options. The purpose of the insurance/repurchase arrangement was to maintain control of the corporation "in the hands of those who were active in the business." Id. 1253.

91 This table is a simplified version of those appearing in $592 \mathrm{~F} .2 \mathrm{~d}$ at 1253.

92 See note 30 supra.

93 See 592 F.2d at 1258 n.7. (The estate's exact post-redemption interest was 81.8276\%.)

94 See text accompanying notes $31-37$ supra. 
cause, even though the estate had sold all its stock, it still owned $82 \%$ through attribution. Likewise, attribution prevented the estate from meeting the substantially-disproportionate test of section $302(b)(2)^{95}$-the estate failed both the $50 \%$ and $20 \%$ tests. ${ }^{98}$ Finally, the redemption was "not essentially equivalent to a dividend" under section $302(\mathrm{~b})(1)^{97}$ because the estate did not achieve a "meaningful reduction" of interest in the corporation; 88 the $82 \%$ attributed ownership sufficed to control all of the corporation's activities. The IRS therefore taxed the redemption as a dividend.

Because the estate's only hope for favorable tax treatment was to dispense somehow with the attribution rules, it filed a statement purporting to waive beneficiary-to-estate attribution, ${ }^{99}$ paid the income tax as assessed, and commenced a refund suit. 100

\section{B. The Fifth Circuit's Decision}

Both waiver and suit succeeded. Despite the apparent lack of a statutory foundation, the Fifth Circuit held that an estate may waive the beneficiary-to-estate attribution of section 318(a) (3) in order to qualify for a complete termination of interest under section 302(b)(3). ${ }^{101}$ The court recognized that this result was inappropriate under a literal reading of the Code, ${ }^{102}$ but rejected such a reading "when the rationale for applying a rule is absent, and

95 See text accompanying notes 38-44 supra.

96 See note 40 supra \& text accompanying notes $39-40$ supra.

97 See text accompanying notes 45-53 supra.

88 See text accompanying note 52 supra. Contra Rickey, 592 F.2d at 1258 n.7. For a discussion of this aspect of Rickey and why it was incorrect, see note 113 infra.

99 The Code does not provide for such waiver. 592 F.2d at 1257; see note 30 strpra. The estate was analogizing its claim to the waiver of family attribution, see note 36 supra \& accompanying text, permitted by $\$ 302(\mathrm{c})(2)$. See 592 F.2d at 1257.

100 The sequence of events actually was more complicated, though not significantly different. The beneficiaries initially treated the redemption as a sale and reported no income. The IRS next audited the estate and beneficiaries, treated the transaction as a dividend, and assessed a deficiency. The estate was then reopened in order to file a waiver. Finally, the beneficiaries paid the assessment, filed for refunds, and, when denied, filed suit. 592 F.2d at 1253-54.

The estate was not reopened until 1973 because the IRS had previously refused to allow an entity to waive any attribution rules. See Rev. Rul. 59-233, 1959-2 C.B. 106. In 1973, the Tax Court, in Crawford v. Commissioner, 59 T.C. 830 (1973), became the first court to hold that an estate could waive family attribution.

101592 F.2d at 1258.

102 "[U]nder a literal reading of the Code, the Rickey estate, regardless of the relationships amongst the estate and the heirs, could not effectively waive the entity attribution rules of $318(\mathrm{a})(3)$." Id. 1257. 
where application of the rule leads to inappropriately harsh results." 103

The rationale was lacking, in the court's view, because "decedent's death was [not] a device to bleed out corporate profits at capital gain rates." 104 The "harsh" result, which apparently was the taxation at ordinary rates, was "inappropriate" because the estate "merely carr[ied] out the provisions of decedent's will" without "motivation ... of benefitting the beneficiaries." ${ }^{105}$ Thus the court fashioned a rule allowing waiver of beneficiary-to-estate attribution whenever an estate, motivated by mandatory provisions of a will, completely terminates its corporate interest. ${ }^{100}$

This new waiver rule is incorrect: it lacks direct precedential support and misperceives the purpose and theory of the redemption and waiver rules. For example, three cases relied upon by the Rickey court for allowing waiver despite the plain language of the Code ${ }^{107}$. are inapposite. Two involved family discord ${ }^{108}$ and were decided under the not-equivalent-to-a-dividend test of section 302 (b) (1), ${ }^{109}$ a section purposely retained from prior law in order to provide a flexible test of redemptions. ${ }^{110}$ In Rickey, however, there was evidence neither of family nor other discord, nor any other positive reason to ignore a presumption of economic identity between actual and constructive owners. ${ }^{111}$ The third case allowed

103 Id. 1258.

$104 I d$.

105 Id. The court did not mention another harsh result: the minor children's portion of the estate would be deprived of capital-gain treatment only because of Junior's holdings in the corporation. This inequity, and a proposed solution, are discussed in text accompanying notes 119-66 infra.

106 This represents a very narrow view of what the Rickey court held. Because of the vagueness of the opinion, however, it would be easy for a court to interpret the opinion more broadly by, for example, not requiring that the will provision be mandatory. To the extent that the rule is interpreted more expansively than it is here, it is even more subject to the criticisms of this section.

107 Haft Trust v. Commissioner, 510 F.2d 43 (1st Cir. 1975); Crawford v. Commissioner, 59 T.C. 830 (1973); Estate of Arthur H. Squier, 35 T.C. 950 (1961).

108 Haft Trust v. Commissioner, 510 F.2d 43 (1st Cir. 1975); Estate of Arthur H. Squier, 35 T.C. 950 (1961). In Squier, the discord was actually between executor and beneficiaries, but the Rickey court and others have read the decision as one of family discord. See, e.g., Rickey, 592 F.2d at 1257; Haft Trust, 510 F.2d at $46-47$.

109 See text accompanying notes $45-53$ supra.

110 See text accompanying notes 76-81 supra.

111 See text accompanying notes 67-69 supra. 
an estate to waive family attribution and therefore does not directly support waiver of entity attribution. ${ }^{112}$

The Rickey court's use of the flexible approach of section 302 (b)(1) in the context of section 302 (b) (3) ignores the purposeful separation of the two provisions. ${ }^{113}$ Impatiently calling the attribution and safe-harbor rules "horror stories" 114 comparable to "King Minos's labyrinth in ancient Crete," 115 the court flouted the purpose of providing definite guidance to taxpayers through precise standards. The court's opinion allows a person to put a provision in his will directing his estate to offer all of his stock to the corporation so that the transaction will be treated as a sale and taxed at capitalgain rather than ordinary-income rates, even if the sole beneficiary owns the balance of the outstanding stock.

Although the court was unhappy that all beneficiaries were taxed at ordinary rates though the deceased's death was not a taxavoidance scheme to "bleed out corporate profits at capital gains rates," 116 it is not unusual for the method of disposing of property alone to determine the tax treatment of the disposal. Indeed, the Supreme Court has noted, in another context: "Congress having determined that different tax consequences shall flow from different methods by which the shareholders of a closely held corporation may dispose of corporate property, we accept its mandate." 117

Section 302 cannot, therefore, be called a "trap for the unwary," as it was by the district court in Rickey.118

112 Crawford v. Commissioner, 59 T.C. 830 (1973). This distinction was recognized in Rickey. $592 \mathrm{~F} .2 \mathrm{~d}$ at 1257-58.

118 See text accompanying notes 76-85 supra.

The Rickey court also offered a possible alternative holding based on $\$ 302$ (b)(1). 592 F.2d at 1258 n.7. It reasoned that there was a meaningful reduction because the estate completely terminated its actual ownership. This dictum-that attribution is ignored whenever an estate completely redeems its actual ownershipis contrary to the Supreme Court's decision in United States v. Davis, 397 U.S. 301 (1970) (see text accompanying note 51 supra), as well as contrary to the letter of $\$ 302$ (c)(1), see note 30 supra, and Congress's intent. When an estate redeems all its stock, it of course sustains a meaningful reduction in ownership. This, however, does not mean that the beneficiaries suffer a loss of control or ownership. The attribution rules were designed to apply in this type of situation, in which one taxpayer (the beneficiary) uses another related taxpayer (the estate) to "sell" stock at capital-gain rates, while suffering no corresponding reduction of interest.

$114592 \mathrm{~F} .2 \mathrm{~d}$ at 1255.

$115 \mathrm{Id} .1256 \mathrm{n.5}$.

116 Id. 1258.

117 United States v. Cumberland Pub. Serv. Co., 338 U.S. 451, 456 (1950). Compare Cumberland with Commissioner v. Court Holding Co., 324 U.S. 331 (1945). The transactions in these two cases yielded identical economic results but were taxed differently because the methods of achieving those economic results were different.

118 Rickey v. United States, 427 F. Supp. 484, 489 (W.D. La. 1976). 


\section{Rickey and Attribution Policy}

The estate-attribution rules are consistent with their underlying theory if an estate has only one beneficiary; however, when there are several beneficiaries, inequities may arise. Although each beneficiary may be in a different tax posture, each is taxed in the same manner as the others when the estate's stock is redeemed. This was the situation in Rickey. Although the estate was not entitled to capital-gain treatment, ${ }^{110}$ the Fifth Circuit nevertheless allowed the estate to waive attribution and receive capital-gain treatment because of the "harsh result" that would follow a literal reading of the statute. ${ }^{120}$ The purportedly harsh result-that an estate receives a dividend when it terminates its interest in a corporation controlled by the beneficiaries-was indeed intended by Congress ${ }^{121}$ and flows logically from the realistic presumption of identical economic interests. ${ }^{122}$

A closer analysis of Rickey, however, reveals an inequity that the court failed to mention. If the stock had been distributed to the beneficiaries and then redeemed, the minor children would have been entitled to capital-gain treatment under the substantially-disproportionate test of section 302(b) (2). Each beneficiary constructively owned one-third of the estate, so if the stock had been distributed and then sold, their ownership would have been as follows: ${ }^{128}$

\section{OWNership After Distribution to Beneficlaries}

\begin{tabular}{|c|c|c|c|c|}
\hline & \multicolumn{2}{|c|}{$\begin{array}{c}\text { Before } \\
\text { Redemption }\end{array}$} & \multicolumn{2}{|c|}{$\begin{array}{c}\text { After } \\
\text { Redemption }\end{array}$} \\
\hline & Shares & $\%$ & Shares & $\%$ \\
\hline Junior & 1139 & $50 \%$ & 708 & $74 \%$ \\
\hline Minor Children & 941 & $42 \%$ & 80 & $8 \%$ \\
\hline Others & 175 & $8 \%$ & 175 & $18 \%$ \\
\hline Total & 2255 & $100 \%$ & 963 & $100 \%$ \\
\hline
\end{tabular}

Junior's ownership in the corporation would actually have increased as a result of the redemption; therefore, he could not have qualified

119 See text accompanying notes $94-97$ supra.

120 See text accompanying notes 101-12 supra.

121 See text accompanying notes 76-85 supra.

122 See text accompanying notes 56-75 supra.

128 Each beneficiary was a "residuary universal legatee." 592 F.2d at 1253. In the actual facts, each received one-third of the proceeds of the redemption. 
for capital-gain treatment under the test of section 302.124 The minor children, on the other hand, both would have achieved a substantially-disproportionate reduction in ownership under section $302(b)(2)^{125}$ and would thus have been taxed at capital-gain rates. Only Junior, therefore, could have avoided tax by having the estate waive attribution and redeem the shares.

Because the Rickey estate, under a proper reading of the statute, should have paid taxes at ordinary rates, the beneficiary-to-estate attribution rules ${ }^{126}$ forced only the minor children to pay greater taxes than they otherwise would have. This result is ironic because the attribution rules are structured to prevent avoidance by another taxpayer, Junior, with whom the minor children lack a close familial tie and unity of economic interests under those rules. ${ }^{127}$

In this situation-in which some beneficiaries may legitimately realize a sale if the stock is redeemed after distribution-tax treatment depends only on the timing of the transaction. This result, compelling ordinary-income treatment because of poor timing and another's tax-avoidance motives, is inequitable and not required by the rationale of the attribution rules. A more precise analysis of beneficiaries' economic interests would remedy this unfairness.

\section{Proposal for a New Rule}

\section{A. The Analysis}

As shown above, not all beneficiaries of an estate are necessarily in the same tax position. Some may have the same tax liability whether they or the estate has the stock redeemed, while the liability of others may change depending on who has the shares redeemed. Furthermore, there is sometimes hostility between executor and beneficiaries, ${ }^{128}$ and there are undoubtedly situations in which executor and some beneficiaries are hostile to other bene-

If the estate's 1,292 shares had been distributed equally, each beneficiary would have received (and later redeemed) $4302 / 3$ shares. Figures in the text are rounded to the nearest unit.

124 See text accompanying notes 26-53 supra.

125 Each minor child. would have reduced his ownership by $90 \%$-from $21 \%$ to 4\%. This reduction meets both parts of the substantially-disproportionate test-the $50 \%$ test and the $20 \%$ test. See text accompanying notes $39-40$ supra.

126 See note 22 \& text accompanying notes $70-73$ supra.

127 The relationships are not close enough to invoke any constructive-ownership rule. See generally text accompanying notes 56-69 supra. Also note that stock which has been attributed from beneficiary to estate is not reattributed to another beneficiary. I.R.C. $\$ 318(\mathrm{a})(5)(\mathrm{C})$; see text accompanying notes $162-66$ infra.

128 E.g., Estate of Arthur H. Squier, 35 T.C. 950 (1961). 
ficiaries. ${ }^{129}$. Thus, it is not always realistic to presume an identity of interest between the beneficiaries as a class and the estate. ${ }^{130}$ When there is no common economic interest between estate and beneficiary, the rationale for constructive ownership is similarly absent, and there is no motive for tax avoidance. The beneficiaryto-estate attribution rules are thus currently applied even when their rationale is absent, thereby unnecessarily and unfairly depriving some beneficiaries of favorable tax treatment.

This problem could be solved by separating each beneficiary's interest in the estate and treating those interests individually. For the purpose of analyzing stock redemptions, each estate should therefore be divided into as many sub-estates as there are beneficiaries. ${ }^{131}$ Each sub-estate would be deemed actually to own stock to which its beneficiary would be entitled. Furthermore, a sub-estate would be deemed to own all the stock owned, constructively and actually, by its beneficiary. The effect of the redemption would then be considered separately for each sub-estate. The section 302(b) rules would be used as guidelines to see if the redemption sufficiently reduced the sub-estate's ownership such that the redemption should be treated as a sale: some sub-estates might meet the completetermination test; others might achieve substantially disproportionate reductions in ownership; some might find relief under the notequivalent-to-a-dividend test; and, of course, some would be taxed at ordinary rates as dividends.

This solution can be illustrated by application to the facts of Rickey $v$. United States. ${ }^{132}$ Each sub-estate there would actually own one-third of the estate's stock, or 431 shares. $^{133}$ Junior's sub-

129 The problem of breach of fiduciary responsibilities is beyond the scope of this Comment.

130 Reply Brief for Appellant at 9, Rickey v. United States, 592 F.2d 1251 (5th Cir. 1979).

131 No sub-estate need be created for a beneficiary with only a remote or contingent interest.

The beneficiary need not be a natural person. For instance, if a beneficiary of an estate is a trust, the trust is considered a beneficiary for the purpose of dividing the estate into sub-estates, while the cestui que trust need not be considered a beneficiary. The constructive-ownership rules would still apply between the trust and the cestui. Thus, stock owned by the cestui would be attributed to the trust and then to the sub-estate. A trust generally has a longer life than an estate and is effectively an entity separate from its beneficiaries, whereas an estate, because of its short life, should not be viewed for tax purposes as an entity distinct from its beneficiaries. Stock owned by an estate would quickly pass to the beneficiaries so that a beneficiary can be thought of as the owner of the stock shortly after the decedent's death. Partnerships and corporations would be treated similarly to trusts.

132592 F.2d 1251 (5th Cir. 1979).

133 See note 121 supra. 
estate would constructively own his 708 shares, while each minor child's sub-estate would constructively own the child's 40 shares: ${ }^{134}$

\section{SUB-ESTATE OWNERShIP OF STOCK}

\begin{tabular}{|c|c|c|c|c|}
\hline & $\begin{array}{r}\text { Befo } \\
\text { Redem }\end{array}$ & re & $\begin{array}{r}\text { Aft } \\
\text { Redem }\end{array}$ & $\begin{array}{l}\text { er } \\
\text { ption }\end{array}$ \\
\hline & Shares & $\%$ & Shares & $\%$ \\
\hline Junior's & & & & \\
\hline Actual & 431 & $19 \%$ & 0 & $0 \%$ \\
\hline Constructive & 708 & $31 \%$ & 708 & $74 \%$ \\
\hline $\begin{array}{c}\text { Total } \\
\text { Minor Child's }\end{array}$ & 1139 & $50 \%$ & 708 & $74 \%$ \\
\hline Actual & 431 & $19 \%$ & 0 & $0 \%$ \\
\hline Constructive & 40 & $2 \%$ & 40 & $4 \%$ \\
\hline Total & 471 & $21 \%$ & 40 & $4 \%$ \\
\hline
\end{tabular}

This sub-estate division would achieve the same tax effects as if the stock had been distributed and then redeemed: the minor children's sub-estates would have substantially disproportionate reductions, while Junior's sub-estate would be deemed to have received a dividend and be taxed at ordinary rates. ${ }^{135}$

This result is proper. Junior, who has a continuing ownership interest in the corporation, would be prevented from avoiding tax by having stock redeemed through the estate, and the minor children, who actually have suffered a significant reduction in ownership and who have no tax-avoidance motive, would get favorable tax treatment.

Another example may be constructed from the facts of Estate of Webber $v$. United States. ${ }^{136}$ In Webber, father and son each owned half of the outstanding stock of the corporation. The father died and, under the terms of his will, his son was entitled to receive real property and cash, while his three daughters were entitled to the remainder of the estate. The father's stock was redeemed from his estate pursuant to an agreement between him and his son, and the proceeds were placed in a trust for the daughters. Under the proposed analysis, separate sub-estates would be created for the son and daughters. The son's sub-estate would not be deemed to own 
any stock, because it was not entitled to the proceeds of the redemption. ${ }^{137}$ All the estate's stock would be deemed to be owned by the daughters' sub-estates, which would have met the completetermination test when the stock was redeemed. Thus, the redemption would be taxed as a sale because the beneficiaries entitled to the proceeds of the redemption would own no stock attributed to their sub-estate.

This sub-estate approach is more equitable for taxpayers while, at the same time, it furthers the theoretical goals. Beneficiaries would be taxed according to their different economic interests and tax situations. Tax avoidance would still be prevented through the constructive-ownership rules, and taxpayers would be able to determine in advance the tax consequences of a redemption. Further, the analysis may be mechanically applied. Indeed, the only change from current practice is that beneficiaries would be taxed in accordance with their own corporate ownership instead of that of an unrelated party.

\section{B. Implementation}

Although this proposal for partial waiver of the attribution rules gives the result most desirable in theory, it does not at first blush fit into the current statutory scheme. Attribution cannot be disregarded for the safe-harbor rules of sections 302 (b) (2) and (3)-the substantially-disproportionate and complete-termination tests-for the same reasons that the Rickey court should not have allowed waiver. ${ }^{138}$ These provisions are unambiguous, rigid tests demanding mechanical readings.

Courts may, however, offer relief through the section 302 (b) (1) not-equivalent-to-a-dividend test. Although attribution in general fully applies to section 302 (b) (1), ${ }^{139}$ partial attribution is nonetheless appropriate because of the vague, flexible nature of the test. ${ }^{140}$ In fact, courts have used it to ignore attribution altogether. ${ }^{141}$ Finally, the notion of sub-estates coincides with, and plugs a loophole in, recent changes in the Code. ${ }^{142}$

137 See text following note 131 supra. If the son were paid with proceeds from the redemption of the stock, his sub-estate would be deemed to own those shares. Id.

138 See text accompanying notes 76-85 supra.

139 See text accompanying notes 45-53 supra.

140 See text accompanying notes $143-46$ infra.

141 See text accompanying notes 147-61 infra.

142 See text accompanying notes 162-66 infra. 
Congress retained the not-equivalent-to-a-dividend test in the 1954 Code to provide the courts with flexibility; ${ }^{143}$ thus, the court's "inquiry will be devoted solely to the question of whether or not the transaction by its nature may properly be characterized as a sale of stock." 144 A sale is evidenced by reduction of ownership interests ${ }^{145}$ "depend[ing] on the facts and circumstances of each case," and attribution is only "[o]ne of the facts to be considered." 146

Accordingly, courts have used section $302(\mathrm{~b})(1)$ to allow capital-gain treatment despite the attribution rules. For instance, in Estate of Arthur $H$. Squier, ${ }^{147}$ an estate reduced its corporate ownership from over $50 \%$ to $41 \% .^{148}$ Without attribution, the redemption would not have been equivalent to a dividend because of the estate's significant loss of control.140 After the redemption, however, a beneficiary owned $11 \%$ of the stock, ${ }^{150}$ so that the estate's post-redemption ownership, with beneficiary-to-estate attribution, was $52 \%$, not enough to bring about a loss in control. Because of a "sharp cleavage" 151 between executor and beneficiary, the court focused only on the estate's actual ownership, holding that the redemption was not essentially equivalent to a dividend under section 302 (b) (1)..$^{152}$

The court in Haft Trust $v$. Commissioner ${ }^{153}$ also found that attribution was not controlling for section 302 (b) (1) redemptions. Here, trusts for the Haft children had all of their corporate stock redeemed. After application of constructive ownership, however,

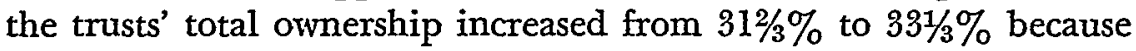
of attribution from father to children and then to the trusts. ${ }^{154}$ The parents had recently undergone an acrimonious divorce, and the children lived with their mother; after the divorce proceedings

143 See text accompanying notes 79-81 supra. 4870-71.

144 S. Rep., supra note 80, at 233-34, [1954] U.S. CoDE Cong. \& AD. NEws at

145 See text accompanying notes 15-18 supra.

146 Treas. Reg. $\$ 1.302-2$ (b) (1955).

14735 T.C. 950 (1961).

148 Id. $950-53$.

149 Id. 955-56.

$150 \mathrm{Id} .952$.

151 Id. 955 . The cleavage is described in id. 951.

152 Id. 955-56.

153510 F.2d 43 (1st Cir. 1975).

154 Id. 46 \& n.2. 
were initiated, the father saw the children only infrequently, ${ }^{155}$ and his support payments were, at best, irregular. ${ }^{156}$ The First Circuit remanded the case for a determination of whether the evidence of family hostility negated "the presumption that taxpayers would exert continuing control over the corporation despite the redemption." 157 The court relied on the decision in Squier ${ }^{158}$ as well as IRS regulations ${ }^{159}$ and legislative history, ${ }^{100}$ concluding that

though a wooden subjugation to the attribution rules might have administrative advantages it could also work injustice in particular cases, and we think that in retaining this section $[(302(b)(1))]$ in the Code alongside the safe harbor rules, Congress showed itself willing to tolerate some administrative inconvenience for the sake of taxpayer equity. ${ }^{161}$

Thus, courts applying the not-equivalent-to-a-dividend test have disregarded the attribution rules when there was evidence rebutting the underlying presumption of economic unity and taxpayers would otherwise be treated inequitably.

In addition, Congress has shown its willingness to eliminate inequitable attribution. Prior to the enactment of section 318 (a) (5) in $1964,{ }^{162}$ stock owned by one beneficiary was partially reattributed to other beneficiaries through the estate. ${ }^{163}$ For instance, in Rickey, all of Junior's stock would have been attributed to the estate, and then one-third of that stock would have been reattributed to each of the minor children. Under this "sidewise attribution," as long as the estate existed the minor children could not have satisfied the complete-termination test even by terminating their actual interests. all.

$155 \mathrm{Id}$. 45. This included one four-year period when he did not see them at

$156 I d$.

157 Id. 48.

$158 \mathrm{Id}$. 46-47. The court said that its prior decision in Bradbury v. Commissioner, 298 F.2d 111 (Ist Cir. 1962), endorsed the Squier "principle that family discord could belie the community-of-interest rationale and was thus a relevant circumstance in determining dividend equivalency under $302(\mathrm{~b})(\mathrm{l})$." $510 \mathrm{~F} .2 \mathrm{~d}$ at 46. supra.

159 Id. 47; see Treas. Reg. $\$ 1.302-2$ (b) (1955); text accompanying note 146

160510 F.2d at 48; see text accompanying notes 76-86 supra.

$161510 \mathrm{~F} .2 \mathrm{~d}$ at 48.

162 Section 318(a)(5) was added by Pub. L. No. 88-554, $\$ 4(a), 78$ Stat. 761 (1964). The relevant portion of $\$ 318(a)(5)$ is reproduced in note 25 supra.

163 See generally, e.g., Loeb, supra note 5, at 431-32; Ringel, Surrey \& Warren, supra note 5 , at $220-21$. 
Congress eliminated this sidewise attribution, recognizing that "there is no basis either in family relationship or in common economic interest for the application of these two attribution rules at the same time." 164 Thus today, the minor children could completely terminate their interests if the estate's stock were distributed to them and all their stock then redeemed; ${ }^{165}$ their taxation would not depend on the holdings of Junior, who would be an unrelated stockholder under the terms of the Code. ${ }^{166}$

Similarly, taxation of their interest in the estate should not depend on Junior's holdings. Although the estate is technically the redeemed shareholder, it is economically more realistic to impose tax consequences as if the beneficiaries were the redeemed shareholders because the estate is generally a short-lived entity and the tax is eventually paid by the beneficiaries. Courts can achieve this treatment through the not-equivalent-to-a-dividend test of section 302 (b) (1). The analysis proposed by this Comment suggests that that tax treatment should depend on the relationship of the individual beneficiary to the estate, and that this procedure fully comports with Congress's intent in retaining section 302 (b) (l) and eliminating sidewise attribution. The alternatives are inequitable treatment for minor shareholders, or, as in Rickey, a loss to the treasury because of an undeserved windfall to majority shareholders. If the courts do not act to resolve the problem, Congress should eliminate the incongruity in the Code by adopting this Comment's proposal.

\section{CONCLUSION}

The Fifth Circuit, in Rickey $v$. United States, ${ }^{167}$ held that an estate may waive the entity-attribution rules when stock that it holds is redeemed by the corporation. The court neither fully nor satisfactorily explained its reasoning. It allowed the taxpayer sale treatment under the complete-termination test of section 302 (b) (3), although it recognized that its holding was inconsistent with a literal reading of that section. The decision was based on what the court said was an unintended inequity in the Code. A discussion of the legislative history and the theory of the attribution rules and stockredemption tests, however, reveals that the result which the court

164 S. Rep. No. 1240, 86th Cong., 2d Sess. 7, reprinted in [1964] U.S. ConE CoNG. \& AD. News 3396, 3402.

$105 C f$. text accompanying notes 123-25 supra (if minor children redeemed only distributed shares, they would today qualify for substantially-disproportionate redemption).

$106 \mathrm{Cf}$. $i d$. (Junior gets dividend treatment because he retains control).

167592 F.2d 1251 (5th Cir. 1979). 
labored to avoid was indeed intended by Congress and accords with tax policy and theory. The analysis also highlights an inequity which the Fifth Gircuit failed to note-one beneficiary's inheritance may unfairly suffer because of an unrelated beneficiary's stock holdings.

The proper tax treatment of corporate redemptions by estates is to attribute a beneficiary's holdings only to his own portion of the estate. Courts can implement this treatment within the framework and policy of the section 302(b)(1) not-equivalent-to-a-dividend test without flouting the current statutory and administrative scheme. The result will be increased judicial flexibility and greater guidance and equity for taxpayers. 